\title{
Sendromik Obez Olgularımızın Klinik Olarak Değerlendirilmesi
}

\section{Clinical Evaluation of Our Syndromic Obese Children}

PInar KOCAAY, Derya TEPE

Ankara Şehir Hastanesi, Çocuk Hastanesi, Çocuk Endokrinoloji Kliniği, Ankara, Türkiye

öz

Amaç: Obezite; Türkiye'de ve dünyada, sıklığı giderek artan obezitenin nadir ancak önemli bir nedenidir. Çalışmada amaç; obe ve fizik muayene bulguları ile sendromik obeziteden şüphenilme tanı konularak hayatı tehdit edebilecek ek anomalilerin erken fark Gereç ve Yöntemler: Bu çalışmada Ankara Şehir Hastanesi, Çod vinoloji polikliniğine Ocak 2019-Ocak 2021 tarihleri arasında başvurmuş ve bu yıllarda takip edilmekte 18 a sendromik obez olgu dahil edilmiştir. Olguların fizik muayene ve antropometrik değerlendirmele yulguları, görme ve ișitme muayeneleri, renal ve hepatobiliyer görüntülemeleri, ekokardiyografik değerlen lerı, psikiyatrik değerlendirmeleri, ek hastalıkları, kullandıkları ilaçlar ve mevcut genetik sonuçları dosyaları taranarak__unmıştır.

Bulgular: Çalışmaya toplam 17 olgu dahil edildi Bu erın dg kız, sekizi erkekti. Olguların en erken tanı yașı 2 yaş; en geç tanı yaşı 12 yaş 6 aydı. Dört olgu Hü üç olgu Bardet Biedel sendromu, altı olgu Alström sendromu, dört olgu psödohipoparatiroidi Tip1 A ta. ur. șikayeti 13 olguda kilo fazlalığı, aşırı yeme isteğiydi. Ancak psödohipoparatiroidi nedeniyle bașvur olgununki boy kısalığıydı.

Sonuç: Olgularımızda en erken tanı yaşı $\quad$ çocuk poliklinik muayenelerinde fizik muayene ve anamnez iç olgn başvuru şikayeti hipokalsemiye bağlı semptomlar iken, bir alımının daha dikkatli yapılması gerektiğ go istir. Ayrıca olguların son poliklinik muayeneleri obezitenin önlenmesi

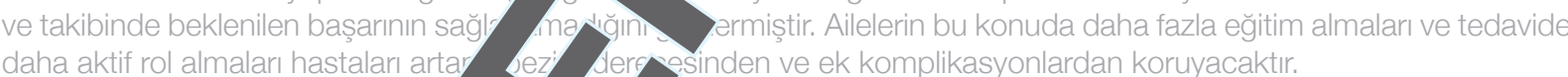
Anahtar Sözcükler: Çocuk, G

\section{ABSTRACT}

Objective: Obesity is an in and physical exart an in findings should besity. Aim of the study is bringing to mind the question of which history
buster diagnosis and treatm additional life-threatening anomalies will be provided in these cases.

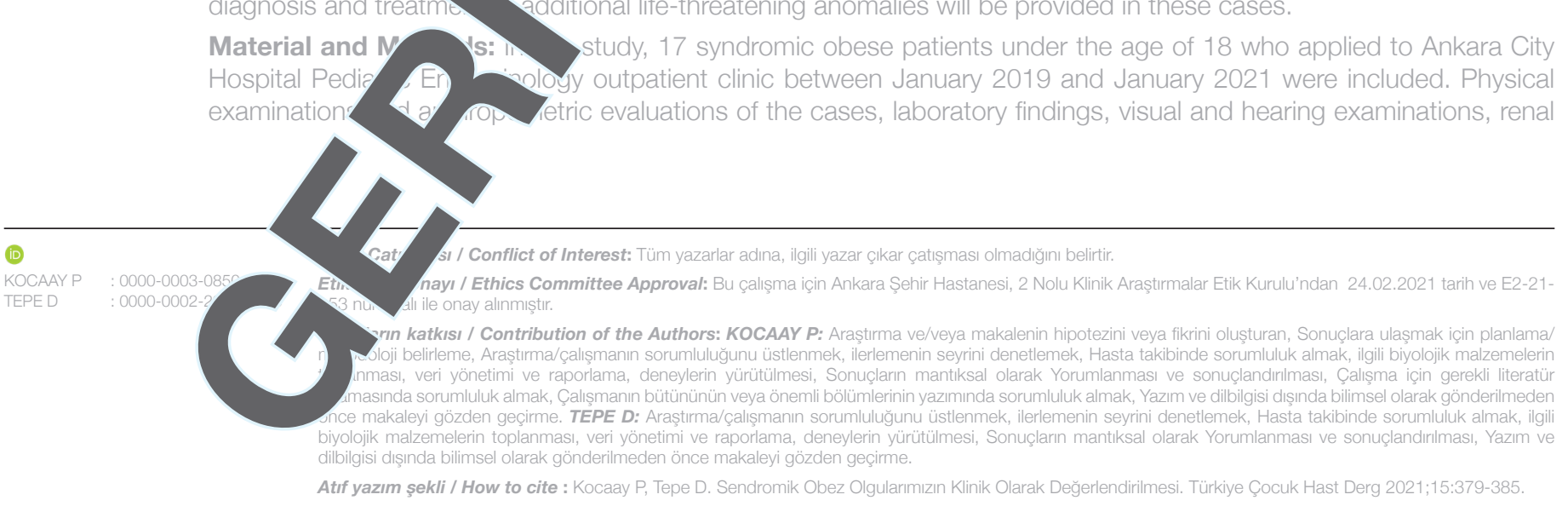


and hepatobiliary imaging, echocardiographic evaluations, psychiatric evaluations, additional diseases, their medications and available genetic results were collected by scanning the patient files.

Results: A total of 17 cases were included in the study. Nine of these cases were girls and eight were boys. The earliest diagnosis age of the cases was 2 years and the latest diagnosis age was 12 years and 6 months. Four cases were diagnosed with Prader Willi syndrome, three cases with Bardet Biedel syndrome, six cases with Alström syndrome and four cases with pseudohypoparathyroidism Type 1 A. The application complaint was excess weight and desire to eat in 13 patients. However, three patients who diagnosed with pseudohypoparathyroidism had hypocalcemia and the other one had short stature.

Conclusion: The fact that the earliest diagnosis age was 2 years in our cases showed that polyclinic phys andions and taking anamnesis should be done more carefully. In addition, the last outpatient clinic examinations of the cases sho the success could not be achieved in the prevention and follow-up of obesity. If families get more education on t subs take Important role in treatment, patients will be protected from increased obesity and additional complications.

Key Words: Child, Genetics, Obesity

\section{GiRiş}

Obezite; organlarda ve yağ dokusunda anormal yağ birikimi sonucu ortaya çıkan; diyabet, hipertansiyon, dislipidemi, kalp damar hastalıkları, kanser gibi birçok hastalığa zemin hazırlayan, Türkiye'de ve dünyada sıklığı giderek artan önemli bir halk sağlığı sorunudur. Bu durum birçok psikolojik problemi de beraberinde getirmektedir. Özellikle ilk 1 yaș, 5-7 yaș ve puberte döneminde sık görülür (1).

Sağlıksız beslenme alıșkanlıkları, fiziksel hareketsizlik, daha nadiren hormonal bozukluklar ve genetik faktörler obezitenin olușmasında rol oynar. Bu nedenler; birincil, ikincil ve gen olarak sınıflandırılabilir.

Birincil (basit) obezite nedenleri; herhangi bir patoloji olmac așırı enerji alınıp buna karșlık yetersiz fiziksel aktivite yay sonucu görülen bir durumdur. Çocukluk çağında obezitenin \%90'nını bu grup olușturur. İkincil obezite endokrinolojik, organik ya da kronik ilaç kullanım çıkar. Üçüncü ve nadir görülen obezite kaynaklı obezitedir. Enerji alımı ve harcanın genlerdeki sorunlar nedeni ile ortaya ck poligenik olabilir.

Monogenik obezite, leptin melanokortin eks birinin fonksiyon kaybı sonucu

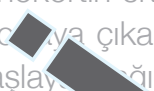

Ikan

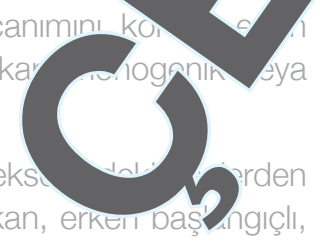
genellikle 7 yașından önce bașlay ŭır bir obezite tipidir. Hatalı genler Leptin, Leptin reser..... MC4R reseptörü

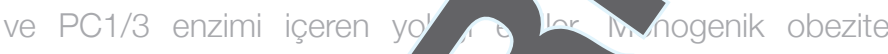
sendromik ve sendromik olr an larak değerlendirilir (2).

Sendromik obez olo da bezlde, hiperfaji, gelișimse anomaliler, dismorfik gar, gan anomalileri, mental retardasyon ve hipotalam siyon eşlik eder (2,3). Obezite ile başvuran bir gurd vaşlayan (özellikle 7 yaşından önce görülen) zzite $\mathbb{1}$ ye eşlik eden hiperfaji, gelişimsel anomaliler, disn k bul ar ve mental retardasyonun varlığ akla sendromik on, getirmelidir. Prader Willi Sendromu, Bardet Biedel Sendromu ve Alström Sendromu klinik pratikte en sık karşılaşılan obezite sendromlarıdır (4).

Bu çalıșmada, nadir görülen sendromik obez olgular değerlendirilmiștir. Çalıșmanın amacı obezite ile bașvuran olgularda sendromik ob eunelenilmesi gereken hikaye ve fizik muayene by çarına an cekmektir. Bu sayede sendromik obez ol anrushis ve tedavisi; hayatı tehdit edebilecek ek ano fark edilmesi sağlanabilecektir.

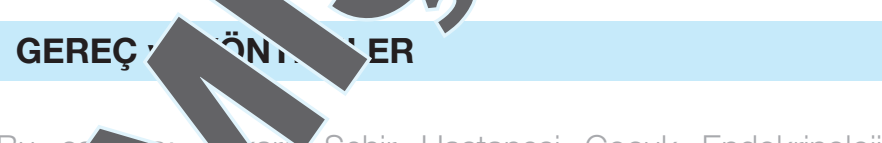

Bu ç Şehir Hastanesi Çocuk Endokrinoloji poliklin 19-Ocak 2021 tarihleri arasında bașvuran 18 yaș alti lguların dosyaları retrospektif olarak taranarak vilmiştır. ENavkin bir nedenle (hipotiroidi, Cushing sendromu, a sebeple ilaç kullanan hastalar (glukokortikoid, hasta.gl olan (beyin tümörü) ve basit obezite düșünülen hastalar haya dahil edilmemiştir. Öykü ve fizik muayene bulgularıyla sendromik obezite düşünülen tüm olguların antropometrik içümleri, laboratuvar bulguları [(Açlık kan şekeri, açlık insülin, alanin aminotransferaz (ALT), aspartat aminotransferaz (AST), trigliserit, total kolesterol, düşük yoğunluklu lipoprotein (LDL), yüksek yoğunluklu lipoprotein (HDL), kalsiyum, fosfor, parathormon $(\mathrm{PTH})]$, görme ve ișitme muayeneleri, renal ve hepatobiliergörüntülemeleri, ekokardiyografik değerlendirmeleri, psikiyatrik değerlendirmeleri, ek hastalıkları, kullandıkları ilaçlar ve mevcut genetik sonuçları dosyalarından taranmıştır.

Çalışmaya alınan çocukların boyları Ayrton Stadiometre (Ayrton Corporation 5322, USA) markalı boy ölçer, kiloları Barimed Electronic Body Scale SC-105 (China) markalı ağırlık ölçer ile ölçüldü. Hastalar obezite değerlendirmesine alınırken boya göre ideal ağırlık kullanılmıștır. İdeal ağırlık yüzdesi \%90-110 arası normal, \%110-120 arası fazla kilolu, \%120-140 arası obez, $\geq 140$ ise morbid obez olarak değerlendirilmiştir (5).

Ulusal Lipid Derneği 2014'e göre hastaların TG $\geq 150$ veya $L D L \geq 130$ mg/dl olması durumunda dislipidemi teşhisi konuldu. İnsülin direnci, (HOMA-IR) homeostasis model of insülin resistance değerlendirmesi kullanılarak değerlendirildi [HOMAIR: açlık glukozu (mmol/L) x açlık insülini ( $\mu \mathrm{u} / \mathrm{L})$ /22.5]. İnsülin direnci, HOMA-IR seviyesi >3.16 olan çocuklarda tanımlandı. Ayrıca prepubertal dönemde insülin direnci (HOMA-IR'ye göre) erkeklerde 2.67, kızlarda 2.22 ve pubertal dönemde erkeklerde 5.22 ve kızlarda 3.82 olarak tanımlandı. Bozulmuș 
açlık glukozu, hiperinsülinemisi ve ciddi insülin direnci olan ve fizik muayenesinde yaygın akantozu olan hastalara Oral glukoz tolerans testi (OGTT) yapıldı. ADA 2014 prediyabet ve diyabet tanı kriterlerine göre kriterleri karşılayan hastalara bozulmuş açlık glukozu (BAG); bozulmuş glukoz toleransı (BGT) veya Tip 2 DM tanısı koyuldu. Açlık glukozu 100-126 mg/dl olan ve oral glukoz tolerans testinde 2. saat glukoz seviyesi <140 mg/dl bulunan hastalara BAG tanısı koyuldu. Standard doz oral glukoz yüklemesi sonrası bakılan 2. saat glukoz seviyesi $>140$ mg/dl ile < 200 mg/dl olan hastalara BGT tanısı koyuldu. Poliüri, polidipsi ve açıklanamayan zayıflama ile birlikte rastgele plazma glukoz değeri >200 mg/dl, açlık plazma glukoz değeri >126 mg/dl veya OGTT 120. dk plazma glukoz düzeyi >200 mg/dl olan hastalara da Tip 2 DM tanısı koyuldu. Hastane laboratuvarımızda kullanılan ALT kitlerinin referans seviyelerine göre, kadınlarda > 22 U/L ve erkeklerde > 25 U/L ALT seviyeleri, yüksek karaciğer enzimleri olarak kabul edildi (6).

Hepatobilier ultrasonografi ile karaciğer yağlanması derecelendirildi: Derece 0: Normal parankimal karaciğer ekojenitesi; Derece I: Damar duvarlarında bulanıklık olmadan artan karaciğer ekojenitesi. Derece II: Damar duvarlarında bulanıklık ile artan karaciğer ekojenitesi. Derece III: Karaciğer ve diyafram arasındaki normal kontrastın kaybolmasına artan karaciğer ekojenitesi.

Bu çalışma için Ankara Şehir Hastanesi, 2 Nolu Araştırmalar Etik Kurulu'ndan 24.02.2021 tarih ve E2 numaralı ile onay alınmıştır.

Verilerin İstatistiksel Değerlendirilmesi İstatistiksel analizler SPSS (versiyon 21.0 IBN kullanılarak yapıımıştır. Tanımlayıcı veriler, sapma (SS) olarak verilmiştir. Normal $\overline{\mathrm{X}} \pm$ SS şeklinde gösterilmiştir.

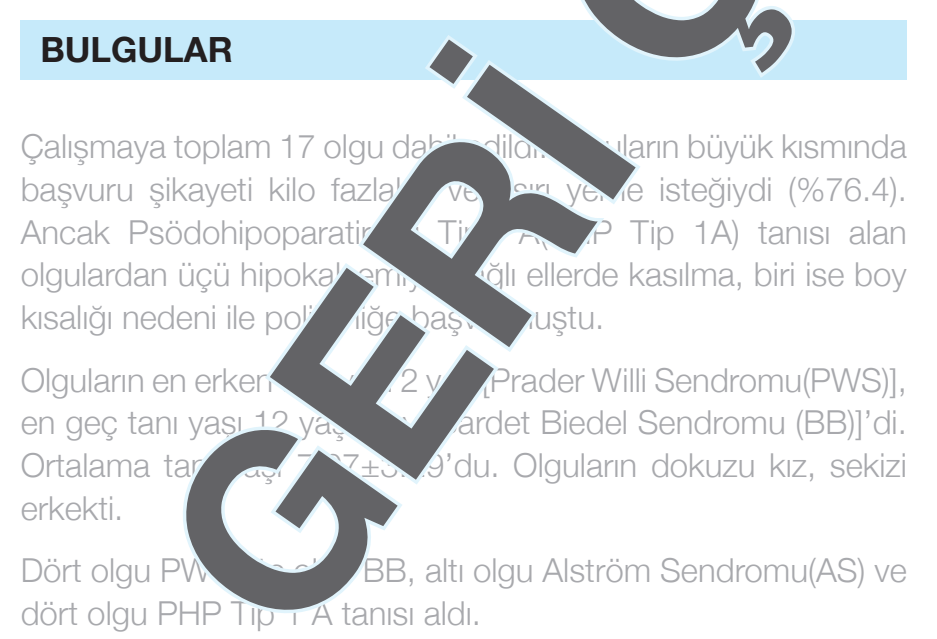

Fizik muayenede BB'li üç olgunun polidaktilisi mevcuttu. PHP Tip 1A düşünülen olgularda 4. metakarpta kısalık ve yuvarlak yüz, PWS'li olgularda dar yüz, badem şeklinde gözler, küçük ağız, ince üst dudaklar, küçük dar eller, AS'li olgularda yuvarlak yüz yapısı ve derin yerleşimli gözler dikkat çeken özelliklerdi.
Puberte muayenesinde BB'li iki olgu ve PWS'li iki olguda inmemiş testis, BB'li bir olguda mikropenis tespit edildi.

Göz değerlendirmesinde, AS'li iki olguda tam görme kaybı, diğer olgularda çeşitli derecede görme kaybı, BB’li kardeş iki olguda retinitis pigmentoza, bir olguda geø rügüü tespit edildi.

Renal ultrasonografi ilk başvur anın olgulara yapıldı.

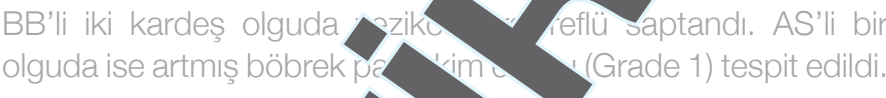
Tüm olgulara yapılan paton valtrasonografide değişik derecelerde karaciğer
mikronodüler siroz manma spit edildi. Bir olguda ise

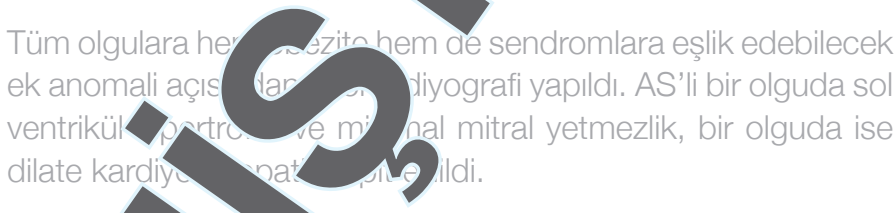
Yapilan Jerlendirmede BB'li iki olgu da mental retardasy quda otizm mevcuttu. PWS'li bir olgu orta me (MR), diğer olgular hafif MR'di. Ek olarak olgu sinirlilik ve obsessif kompulsif bozukluk gibi davrans blemleri vardı. AS'li olguların MR'si yoktu, ancak tüm olgy Özel eğitim alıyordu. PHP Tip1 A tanısı konulan lif MR idi. linik tüm olguların tanısı genetik çalışma ile doğrulandı. 153 olguların bir kısmının genetik sonuçlarına ulaşılamadı. Bir Æmının ise çalışmaları halen devam etmektedir.

Olguların özellikleri ve eşlik eden ek hastalıklar tablo l'de özetlenmiştir.

\section{TARTIŞMA}

Çocuklarda en sık obezite nedeni fazla enerji alımıdır. Nadir ancak dışlanması gereken diğer önemli sebepler; endokrin hastalıklar ve genetik sendromlardır. 2007 yılında 1405 çocuk hastanın retrospektif olarak incelendiği bir çalışmada yalnızca 13 olguda $(<\% 1)$ endokrin ve genetik hastalıklar saptanmıştır (3). Bu çalışmada da 2 yıllık süre boyunca sadece 17 sendromik olguya ulaşılmıştır.

Sendromik obez olgularda geç tanı konulması önemli bir sorundur. PWS'li olgularda yenidoğan döneminde zayıf emme ve hipotoni nedeniyle tanı konulabilecekken, çalışmamızda 2 yaşından önce tanı konulan PWS hastası yoktu. BB'li üç olgunun polidaktilisi olmasına rağmen üç olguda çok geç tanı almıştı. Bu durum doktor kontrollerinde ayrıntılı hikaye alınmaması ve fizik muayene yapılmamasından kaynaklanıyor olabilir.

PWS çocukluk çağında en sık görülen obezite sendromudur. Sıklığı 1:10000-1:15000 arasındadır $(7,8)$. Bu sendrom 15q11.2- q12 paternal segmentte delesyon veya kromozomal kayıp nedeniyle oluşur (9). Delesyonlar vakaların \%70-80'inde saptanabilir. Bu çalışmada dört olguda genetik çalışma ile delesyon saptanıp PWS tanısı aldı. Olgular yenidoğan 
Tablo I: Sendromik obez olguların klinik bulguları.

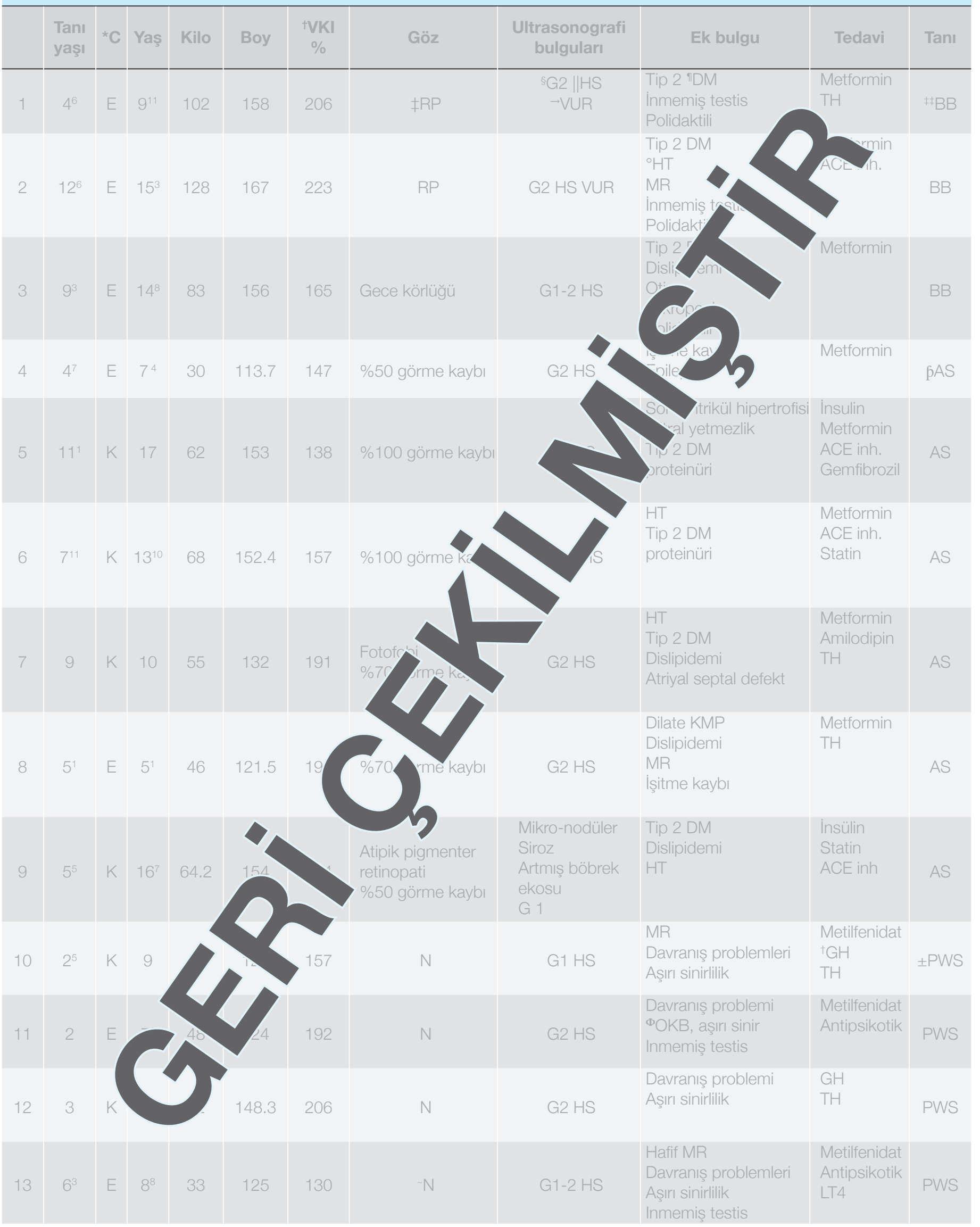




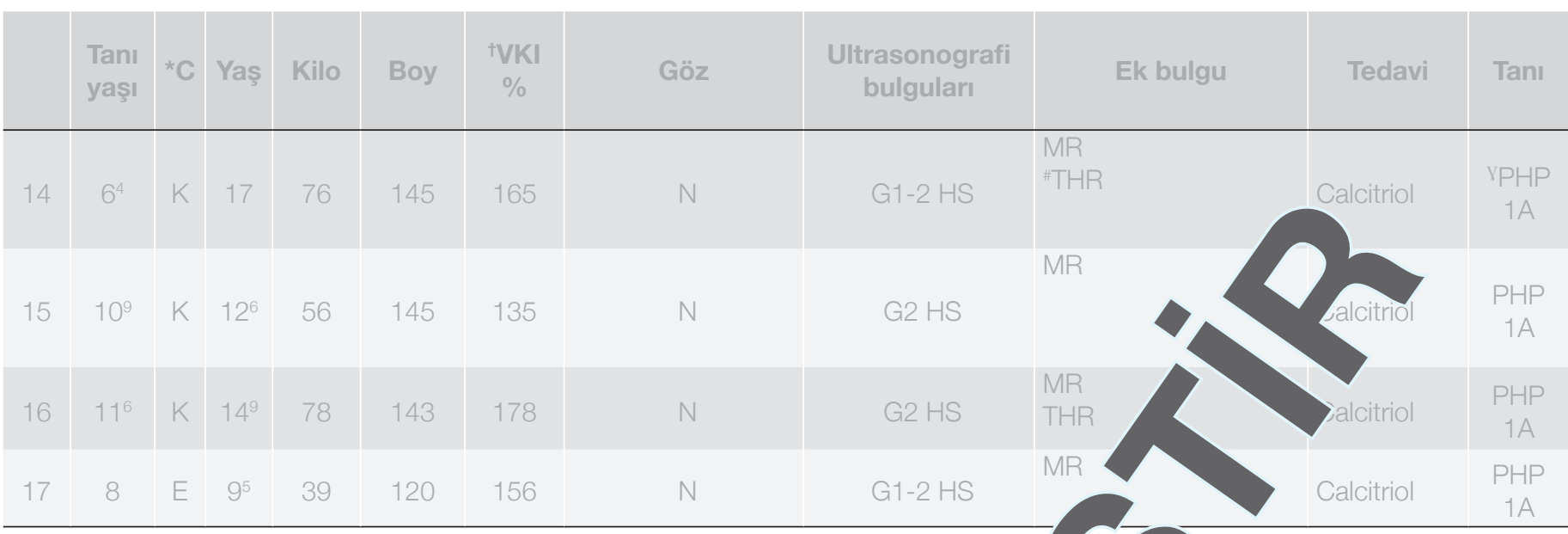

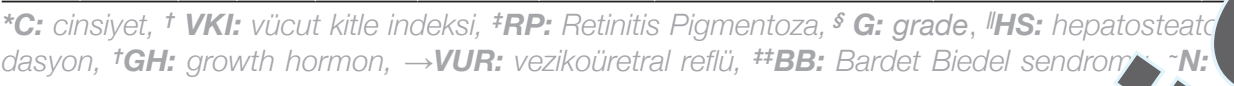

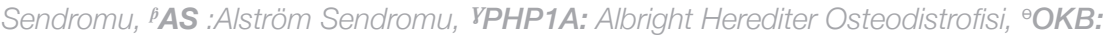

DN tes Mellitus, ** MR: mental retar (n) lipertansiyon, ${ }^{ \pm} P$ WS: Prader Will "THR: tiroid hormon direnci döneminde zayıf emme, hipotoni, gelişme geriliği șikayeti ile başvururken, genellikle bir yaşından sonra ise aşır iştah, boy kısalığı, davranış problemleri, psikiyatrik hastalık ile gelirler. Bu çalışmadaki 4 olguda da yenidoğan döneminde hipotoni ve zayıf emme vardı. Fizik muayenede; dar yüz, badem şeklinde gözler, küçük ağız, ince üst dudaklar, küçük dar eller, kısa geniş ayaklar genital hipoplazi dikkat çeken bulgulardır. Tüm olgularda da tip yüz bulguları mevcuttu. Davranış problemleri bu sendrom hayatı ciddi etkileyen bir durumdur. Dört olguda da davral problemleri mevcuttu ve psikiyatrik ilaç kullanmalarına ră tam düzelme sağlanamamıştı. Literatürde bu konuda tedavi yöntemleri önerilmektedir. Örneğin oksitosinj ye B sendromu otozomal resesif geçiş gösterir. Genel olarak sıklığı davranışı, sosyal ilişki, emosyonel aktivite üzerinde tif olduğunu savunan bir çalışmada 24 PWS'li olg oksitosin verilmiş ve fayda gördüğü iddia edilm söylemin geçerli ve tüm hastalara uygulanaby fazla çalışma yapılmalıdır (10). Bu sendro büyüme hormonu disfonksiyonu,

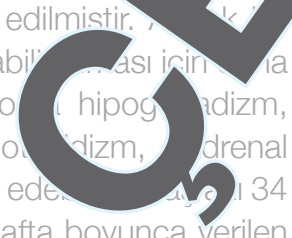
sık olduğu toplumlarda daha sık görülür. Bu çalışmada BB sendromlu üç olgu vardı. İki olgu kardești ve anne babası 1. derece kuzen evliliği yapmıştı. yetmezlik gibi birçok endokrin hastalı eșlik edd büyüme hormonunu tedavisinin boy S -rut kompozisyonu, motor ve kognitif durumu iyileşt ond varımışı (11).

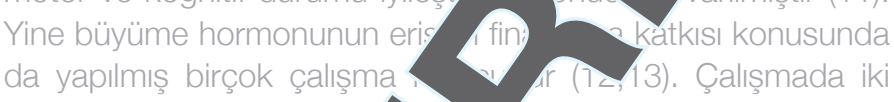
olguya büyüme hormony lavi Janmışt, diğer olguların izlemi sürmektedir. Çall' adj en PWS'li olgu inmemiş testis nedeniyle opere üç olguya hipotiroidi nedeniyle tiroid hormon to sanmıșt. Adrenal yetmezlik
takip sırasında hil. Yapılan bir çalış (da y Mdan önce tanı konulan PWS'li olgularda obezite Ita Ikma yașı 10 yaş, 1-3 yașında tanı konulan olgularda obezıu nin ortaya çıkma yaşı 6 yaş, 3 yaşından sonra tanı konulan olgularda ise obezitenin ortaya çıkma yaşı 4 yaş olarak saptanmıştır (13). Literatürden farklı olarak bu çalş̧mada erken tanı konulan olgularda obezite derecesi daha yüksek olarak saptandı. Bu durum olguların mental gerilikleri nedeniyle beslenme önerilerine uymamaları ve ailelerin eșlik
Hastaların doğum kilosu genellikle normaldir, fakat hayatın ilk yılından sonra hızı kilo alımı başlar. BB' de obezitenin mekanizması tam olarak anlaşılamamakla birlikte hem santral (leptinin anorektik yolağı aktive edici etkisine direnç) hemde periferal (adipogenez artışı) nedenlerin rol oynadığı düşünülmektedir (15). BB sendromlu üç olgunun da doğum kilosu normaldi, ancak her üçü de ilk dekatta morbid obez olmuştu.

Ekstremite anomalileri bu sendromun temel özelliklerinden biridir ve tanı koymada en önemli ipuçlarından biridir. En yaygın șekli; her iki el ve ayakta polidaktili ve brakidaktilidir (15). Tüm olgularda bu durum mevcuttu ve yaşamın illk beş yllı içinde üç olgu da opere olmuştu.

Retinal distrofi sendromun diğer bir özelliğidir. Hastalarda \%100 oranında görülür. Klasik şekli, retinitis pigmentozadır. Retinal disfonksiyonun illk işareti gece körlüğüdür. Ayrıca, optik atrofi, iris kolobomu, bilateral aniridi, katarakt, miyopi ve eksternal oftalmoplejiye de rastlanmıştır (15). Literatürle uyumlu olarak her üç olguda göz muayenesi sonucunda retinitis pigmentoza saptanırken; bir olguda gece körlüğü mevcuttu. 
Mental retardasyon bu sendromda görülen diğer önemli özelliktir ve olgularda \%80-90 oranında görülmektedir. Yapılan bir çalışmada IQ puanı 79'un altında olan hasta oranı \%44 olarak bulunmuştur (15). Bu çalışmada kardeş olan iki olgu mental retardeydi. Diğer olguda ise otizm vardı. Otizm ise literatürde de

BB'li olgularda genital anomaliler erkek çocuklarda kılardan daha sık rapor edilmektedir. Bu çalısmada iki olgu inmemiş testis nedeniyle opere olmuştu ve diğer olguda ise mikropenis mevcuttu.

BB sendromlu olgularda renal bulgular genellikle siliktir, ancak radyolojik olarak yapısal defekt genel olarak vardır. Poliüri çocukluk çağında en erken saptanan semptomdur. Kistik böbrek displazisi, üretral stenoz, hidronefroz, vezikoüretral reflü, vezikovaginal fistül ve üretral sinüs görülebilir. Kronik böbrek yetmezliği bu grup hasta için en sık ölüm nedenidir. Yapılan postmortem 57 olguluk bir çalışmada renal yapısal anomali $\% 46$ oranında saptanırken; sadece \%5 hastada fonksiyonel yetersizlik tespit edilmiştir (15). Yine Türkiye'den yapıımış 23 BB'li olgunun incelendiği bașka bir çalışmada tüm hastalarda renal anomali saptanmıștır (17). Literatüre benzer șekilde bu çalıșmadaki iki olguda da vezikoüretral reflü vardı. belirtildiği gibi BB'li olgularda nadir görülen bir durumdur (16).

hiperinsülinemi çok erken yaşta başlarken, \%80 olguda Tip 2 DM 16 yaşından sonra ortaya çıkmaktadır $(19,20)$. Tüm olgular Tip 2 DM için oral antidiyabetik kullanırken; iki olgu beraberinde insülin kullanıyordu. Olgular diyabet tanısını 10 yaşından sonra almışlardı.

Bu sendroma ilerleyici kronik böbrev vetmezliği, karaciğer fonksiyon bozukluğu, dilate kar pratiye sekonder konjestif kalp yetmezliği de eș ede iki olguda idrarda artmış protein atılım mevcuttu ve her ikisi de ACbitallaniyordu. Genç hastalarda mortalite dil ka viyopatiye sekonder kalp yetmezliğinden olay 9). 38 s.li çocuk ve erişkin olguyla yapılan bir şma Kardiyak değerlendirmede infantil kardiyomyop küsü ola AS'li hastalarda kardiyak fonksiyonun yaşan Illk inda iyileştiğini ancak tamamıla normale dönedi ektedir. Aslinda AS'li çocuk ve yetişkinlerk ğun fonksiyonunda rezidüel bir bozukluğun ola vilinmek edir (19). Bu çalışmada yapılan kardiyolojik adr bir olguda dilate kardiyomyopati, bir olguda m al yetmezlik ve sol ventrikül hipertrofisi tespit ürkiye'den bildirilmiş bir vakada 13 yaşında kliniğe

BB'de en önemli morbidite nedeni șișmanlığa bağlı Tir ka karaciğer tutulumu karaciğer enzimlerinin Diyabetes Mellitus(DM), hipertansiyon ve hiperkolesterolemidir. pen, hepatosteatoza hatta portal hipertansiyon ile Her 3 olguda da ciddi insülin direnci ve Tip 2 DM oln slroza kadar ilerleyen bir dağlım gösterdiği bilinmektedir.

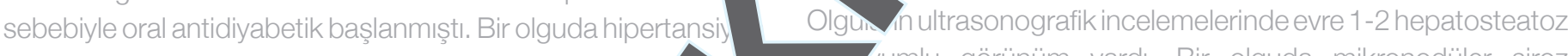
nedeniyle enapril kullanıyordu. BB'li 15 çocuğun aileleri ile yapıımış bir çalışmada; n’ gärüt mevcuttu.
bozuklukların aile hayatını nasıl etkilediği, günlly erişkin AS'li hasta ile yapılan bir çalışmada AS'li olgularda karşılaştıklarında yeterli destek alan ebeveyn gerekililiği vurgulanmaktadır (18). Ancak bu bizim ülkemizde gözardı edilmektedir.

AS, ALMS1 geninde mutasyon sonucu olus obezite, görme kaybı, işitme
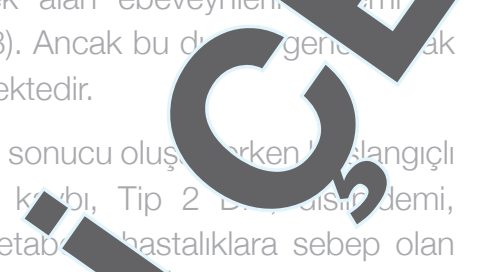
hipotiroidi gibi endokrin ve metal castalıklara sebep olan otozomal resesif geçişli bir hastalıkt remiz gibi akraba evliliklerinin yaygın olduğu toply an ș. gur. Bu çalışmada altı olgu AS tanısı aldı. Dört da ikisi kardeş olgulardı. Fizik ulguları unın her olguda farklı olabilmesi nedeniyle tan karma değildir. Literatürdeki olguların birçoğunda ư̈ yy rlak yüz yapısı ve derin yerleşimli gözler bu çan tal gularda da mevcuttu (19). Olgularda bebel paşlayan ve ilerleyen yașlarda körlük ile sonur an ôjenerasyon önemli bir bulgudur. Bu çalışmada olguy ja tipik olarak bir yașından önce başlayan nistagn tofobi mevcuttu. Kardeș iki olguda \%100 görme kaybı, diğer olgularda ise değişik derecelerde görme kaybı mevcuttu.

Bu olgularda Tip 2 DM, hipertrigliseridemi ve hipotiroidi gibi endokrin komplikasyonlar görülebilir (20). İnsülin direnci ve erken bașlayan ve hızlı ilerleyen böbrek hastalığı olan olgularda genç yaşta kronik karaciğer hastalığının yüksek olarak görüldüğü bildirilmiştir (22). Ancak bu çalışmada AS'li olgulardan sadece birinde artmış böbrek parankim ekosu saptandı.

AS'li olgular genellikle normal zeka yapısına sahiplerdir, ancak öğrenme güçlüğü görülebilir. Çalışmadaki tüm olgular özel eğitim alıyordu. Olguların yaşıtlarından geriliği, eşlik eden görme ve işitme kaybı nedeniyle olduğu düşünüldü.

Psödohipoparatiroidizm; düşük kalsiyum, yüksek fosfor ve parathormon düzeyleri ile karakterize hedef organların parathormona $(\mathrm{PTH})$ yanıt vermediği kalıımsal bir bozukluktur. Bu hastalarda PTH'ye son organ cevabı yetersizdir. Tip 1A formunda biyokimyasal özelliklere ek olarak Albright Herediter Osteodistrofisi (AHO) olarak bilinen karakteristik bir fenotip (obezite, mental retardasyon, yuvarlak yüz, kısa boy, brakidaktili, hormon direnci) görülür. Çalışmada psödohipoparatirodi tanısı alan $\mathrm{AHO}$ fenotinde dört olgu vardı, olguların genetik analiz sonuçları halen beklenmektedir. PHP tip 1A'lı hastalarda Gas ekspresyonunu veya işlevini oluşturan GNAS'ta defekt vardır. Sadece PTH'ya değil; TSH, gonadotropinler, glukagon, kalsitonin ve büyüme hormonu salgılatıcı hormon gibi ilave hormonlara da direnç gösterirler (23). Primer hipotiroidi ve 
hipogonadizme yol açar (24). Eşlik edebilecek diğer hormon direnci açısından bakıldığında iki olguda hafif tiroid hormon direnci vardı.

Bu çalışmayı sınırlandıran durumlar olgu sayısının az olması ve tüm olguların genetik sonuçların olmamasıdır.

\section{SONUÇ}

Obezite nedeni ile başvuran olgularda hastanın özgeçmişinin, aile öyküsünün dikkatli sorgulanması ve yapılan fizik muayene ile birincil ve ikincil obezite nedenlerin dışlanması çoğunlukla sağlanabilecektir. Öyküde erken başlangıç (özellikle 5 yaşından önce) ve beraberinde aşırı yeme davranıșı önemli bir ipucudur. Obeziteye boy kısalığı, mental retardasyon, ekstremite anomalileri, hipogonadizm, göz bulguları, organ disfonksiyonu gibi bulgular eşlik ediyorsa, primer obezite nedenlerinden uzaklașılarak diğer obezite nedenleri araștırımalıdır. Obez çocuklarda eșlik eden birden fazla sisteme ait bulgu varlığında olgularda ayırıcı tanıda sendromik obezite de düșünülmelidir. Bu olgularda kognitif fonksiyonlar değerlendirilmeli, göz muayenesi, kardiyak ve renal görüntüleme yapılmalıdır.

7. Chung WK, Leibel RL. Molecular physiology of syndromic obesities in humans. Trends Endocrinol Metab 2005; 16: 267-72.

8. Cassidy SB, Dykens E, Williams CA. Prader willi and Angelman syndromes:sister imprinted disorders.Am J Med Genet 2000;97:136-46.

9. Angulo MA, Butler MG, Cataletto ME. Prader -Willi syndrome: A review of clinical, genetic, and endo dings. J Endocrinol Inves 2015;38.1249-63.

10. Miller JL, Tamura R, Butler N, Sulsora C, Gold JA et al. Oxytocin treatment in ader-Willi syndrome: A double- blind, placebo-cor $>$ study. Am J Med Genet A 2017:173:1243-5r

11. Yang A, Choi JH, Sohn Y Lee J, Yoo HW, et al. Effects of recombinant human grath tho treatment on growth, body composition, and s. in infants toddlers with Prader-Willi syndrome: a rand
Dis 2019 Seco 11;

12. Lindgren normalizes

Willi syn

Databas

13. Angun MA, Jana M, Lamerson M, Arguello R, Accacha S, L vult height in children with Prader-Willi syndrome with a uman growth hormone treatment. Am J Med Genet $A \geq 43: 1456-61$

Dibia Liz Yoricona Alfaro, Perrine Lemoine, Virginie Ehlinger. Bu çalışmadaki olgularda en erken tanı yaşının 2 yaş olması çocuk poliklinik muayenelerinde fizik muayene ve anamnez alımır daha dikkatli yapılması gerektiğini göstermiştir. Sendromik obe olgularda ihtiyaç olan uygun tedaviye zamanında başlanabilme eşlik eden organ disfonksiyonunun ve özel eğitim gerektirec 4 mental durumların tespiti açısından erken tanı çok ön Özellikle genel pediatristlerin bu duruma aşina olm ve tedavinin daha erken başlamasını sağlayacak yaşam kalitesini iyileştirecektir.

Ayrıca olguların son poliklinik muayeneleri obe ve takibinde beklenilen başarının sağlanam Ailelerin bu konuda daha fazla eğitim alma aktif rol almaları hastaları artan obezite komplikasyonlardan koruyacaktı.
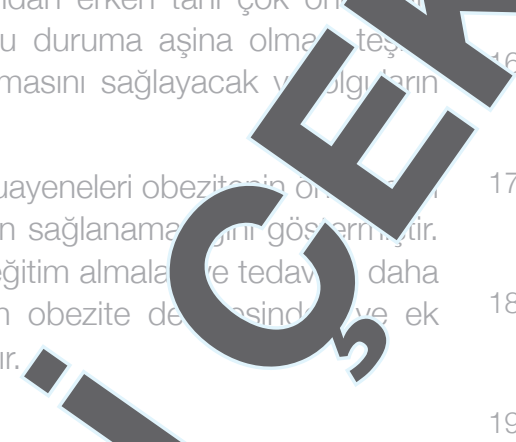

17. Atmıș B, Bayazıt AK, Melek E, Bişgin A, Anarat A. Renal features of Bardet Biedl syndrome: A single center experience. Turk J Pediatr 2019;61:186-92.

18. Deniz Z, Finn RH, Charlatte von der L. Caring for a child with BardetBiedl syndrome: A qualitative study of the parental experiences of daily coping and support. Eur J Med Genet 2020;04:01.

19. Brofferio A, Sachdev V, Hannoush H Marshal JD, Naggert JK, Sidenko S, et al. Characteristics of cardiomyopathy in Alström syndrome: Prospective single-center data on 38 patients. Mol Genet Metab 2017;121:336-43

20. Marshall JD, Beck S, Maffei P, Naggert JK. Alström Syndrome. Eur J Hum Genet 2007; 15812:1193-202.

21. Dinleyici EÇ, Kilıç Z, Doğruel N. A case of Alstrom syndrome presenting with dilated cardiomyopathy at 13 years of age Turkiye Klinikleri J Pediatr 2007;16:118-21.

22. Baig S, Paisey R, Dawson C, Barrett T, Maffei P, Hodson J, et al. Defining renal phenotype in Alstrom syndrome. Nephrol Dial Transplant 2020;35:994-1001.

23. Mantovani G, Spada A. Resistance to growth hormone releasing hormone and gonadotropins in Albright's hereditary osteodystrophy. J Pediatr Endocrinol Metab 2006;19:663-70.

24. Mantovani G, Ferrante E, Giavoli C, Linglart A, Cappa M, Cisternino $\mathrm{M}$, et al. Recombinant human $\mathrm{GH}$ replacement therapy in children with pseudohypoparathyroidism type la: first study on the effect on growth. J Clin Endocrinol Metab 2010;95:5011-7. 